\title{
Hypocholesterolemia is an independent risk factor for depression disorder and suicide attempt in Northern Mexican population
}

\author{
Marcela Segoviano-Mendoza', Manuel Cárdenas-de la Cruz'1 , José Salas-Pacheco' ${ }^{1}$, Fernando Vázquez-Alaniz², \\ Osmel La Llave-León ${ }^{1}$, Francisco Castellanos-Juárez¹, Jazmín Méndez-Hernández³, Marcelo Barraza-Salas" \\ Ernesto Miranda-Morales ${ }^{1}$, Oscar Arias-Carrión ${ }^{5}$ and Edna Méndez-Hernández ${ }^{1,6^{*}}$
}

\begin{abstract}
Background: Cholesterol has been associated as a risk factor for cardiovascular disease. Recently, however, there is growing evidence about crucial requirement of neuron membrane cholesterol in the organization and function of the $5-\mathrm{HT}_{1 \mathrm{~A}}$ serotonin receptor. For this, low cholesterol level has been reported to be associated with depression and suicidality. However there have been inconsistent reports about this finding and the exact relationship between these factors remains controversial. Therefore, we investigated the link between serum cholesterol and its fractions with depression disorder and suicide attempt in 467 adult subjects in Mexican mestizo population.

Methods: Plasma levels of total cholesterol, triglycerides, and high-density lipoprotein cholesterol (HDL-c) and low density lipoprotein cholesterol (LDL-c) were determined in 261 MDD patients meeting the DSM-5 criteria for major depressive disorder (MDD), 59 of whom had undergone an episode of suicide attempt, and 206 healthy controls.

Results: A significant decrease in total cholesterol, LDL-cholesterol, VLDL-cholesterol and triglyceride serum levels was observed in the groups of MDD patients and suicide attempt compared to those without suicidal behavior $(p<0.05)$. After adjusting for covariates, lower cholesterol levels were significantly associated with MDD (OR 4.229 Cl 95\% $2.555-7.000, p<.001)$ and suicide attempt (OR 5.540 Cl 95\% $2.825-10.866, p<.001)$
\end{abstract}

Conclusions: These results support the hypothesis that lower levels of cholesterol are associated with mood disorders like MDD and suicidal behavior. More mechanistic studies are needed to further explain this association.

Keywords: Suicide attempt, depression, cholesterol

\section{Background}

Suicide is one of the most disastrous outcomes of psychiatric disorders [1]. It is a significant public health problem and is one of the leading causes of death worldwide [2-4]. In Mexico the rate of suicide is a current health problem that is accentuated by the fact that it is a country with an emerging market economy. In recent years, Mexico has

\footnotetext{
* Correspondence: edna_madai@hotmail.com

${ }^{1}$ Instituto de Investigación Científica, Universidad Juárez del Estado de

Durango, Universidad S/N esquina Volantín Zona Centro CP 34000, Zip Code

34000 Av., Durango, Mexico

${ }^{6}$ Subdirección de Investigación en Salud, Servicios de Salud de Durango, Zip

Code 34000., Durango, México

Full list of author information is available at the end of the article
}

presented an increase in its suicide rate. For example, between 2000 and 2014 there was an increase in the suicide rate from 3.5 to 5.2 cases per 100,000 inhabitants (http:// bibliodigitalibd.senado.gob.mx/handle/123456789/3181) [5].

Suicidal behavior includes a wide spectrum of behaviors, such as completed suicides, high-lethality suicide attempts, and low-lethality suicide attempts [6, 7]. Although roughly $60 \%$ of all suicides occur in the context of depressive disorders $[7,8]$ it is still challenging for clinicians to predict suicide risk in patients with depression. For this reason, increased attention has been paid to potential biomarkers for suicide in patients with major depressive disorder (MDD) and suicidal behavior $[1,9]$. 
Many studies have confirmed that biological markers might be linked to suicidality, among which serum lipid levels might play an important role [2, 10-12]. However, there has been considerable controversy about the association between serum lipid levels and suicidality. Some human studies showed that suicide attempters had lower cholesterol levels $[2,11,13,14]$ others reported positive associations between cholesterol and completed suicide[2, 15-17] and some others indicated that there was no evidence for an association between serum cholesterol and suicidality $[18,19]$.Although the mechanism behind hypocholesterolemia and suicide has not been clearly defined, previous studies have suggested that altered cholesterol at synaptic lipid rafts may cause a reduction in serotonin communication [2].

In the Mexican population, very few studies have examined the association between serum lipid levels and the presence of depression and suicide attempt, and none have reported the frequency of hypocholesterolemia in depressed patients and suicide attempters. Here, we hypothesized that: 1) serum lipid levels are reduced in subjects with depression and suicide attempt; 2) Hypocholesterolemia is a risk factor associated with depression and suicide attempt.

\section{Methods}

\section{Study population}

After the approval of protocol by Research and Ethics Committee of the General Hospital 450 (No. 12/03062015), a case-control study was conducted with 261 MDD adult patients, 59 of these also had a recent episode of suicide attempt and 206 healthy adult volunteer controls of both genders; all subjects provided informed consent. Study subjects were recruited from the Mental Health Hospital "Dr. Miguel Valle Bueno" (Secretary of Health) and psychiatry service of the General Hospital 450 (Secretary of Health) and General Hospital "Dr. Santiago Ramón y Cajal" (ISSSTE), in Durango City, Mexico, from June2015to December 2016.

MDD diagnosis was made by trained psychiatrists according to DSM-5 criteria. We defined suicide attempt as "a non-fatal, self-directed, potentially injurious behavior with an intent to die as a result of the behavior" as defined by the Center for Disease Control and Prevention (https:// www.cdc.gov/violenceprevention/suicide/definitions.html) [20]. For our recruitment, we considered only participants that required hospitalization.Subjects in the case group were matched with subjects in the control group based on age, sex and body mass index (BMI).The latter, in order to exclude nutritional state as a confounding factor and due to previous association between BMI and cholesterol levels. [21]. Control subjects were apparently healthy persons without any symptoms or signs of MDD based on a clinical examination at inclusion. Use of lipid lowering drugs, such as statins was considered a confounding factor due to the diverse effects it may have on cellular mediation of inflammation and immunity [22] in conjunction with its known effect on depression [23] and was, therefore, an exclusion criterion. Lastly, we excluded those with chronic diseases (hepatic disorders, diabetes mellitus, hypertension, cardiovascular disease) due to their association with dyslipidemia. $[24,25]$

\section{Lipid profile}

Blood samples were obtained by venous puncture of all participants after an overnight fasting period. The lipid profiles were determined using the A15 Clinical Chemistry and Turbidimetry Systems (BioSystems) according to the manufacturer's instructions. The level of serum lipids was evaluated based on total cholesterol (TC), high-density lipoprotein cholesterol (HDL-C), low-density lipoprotein cholesterol (LDL-C) and triglycerides (TG).Hypocholesterolemia was defined as a total cholesterol concentration of less than $150 \mathrm{mg} / \mathrm{dl}$.

\section{Statistical Analyses}

Numerical data were presented as mean \pm standard deviation $(S D)$. Categorical variables were presented as proportions. Differences between the two case groups (MDD and MDD associated with suicide attempt) and control group (healthy subjects) were estimated using ANOVA (Kruskall Wallis test for skewed data) for numerical variables with an additional Bonferroni post-hoc test, and the chi-squared test for categorical variables. Additionally, our analysis was stratified by sex and logistic regression analysis was performed to determine the association between hypocholesterolemia (independent variable) and the presence of depression and suicide attempt (dependent variables). Values of $p<0.05$ were considered statistically significant. The Statistical Package for the Social Sciences (SPSS) for Windows version 21.0 (SPSS Inc., Chicago, IL) was used for data management and statistical analysis. Odds ratio (OR) and $95 \%$ confidence interval $(95 \% C I)$ were determined, while $p$ value $<0.05$ defined the statistical significance.

\section{Results}

Clinical characteristics and laboratory parameters of the 467 enrolled subjects are shown in Table 1. The comparative analysis of the serum lipid levels between the study groups showed significant differences in the total cholesterol, LDLcholesterol, VLDL-cholesterol, triglycerides serum levels and, hypocholesterolemia frequency $(p<0.05)$. No significant difference in HDL levels were observed between groups.

Post-hoc analysis between the two groups comprised of patients with MDD with suicide attempt $(p<0.001)$ and MDD only $(p<0.001)$ showed significantly lower total cholesterol levels compared to the control group. Also, patients with MDD who were associated with suicide attempt had 
Table 1 Mean cholesterol levels and hypocholesterolemia frequency according to mental impairment categories

\begin{tabular}{|c|c|c|c|c|}
\hline & Healthy subjects & MDD & $\begin{array}{l}\text { MDD associated } \\
\text { w/suicide attempt }\end{array}$ & $P$ value \\
\hline $\mathrm{n}$ & 206 & 202 & 59 & - \\
\hline Age, years & $36.8 \pm 6.6$ & $37.3 \pm 10.0$ & $35.2 \pm 10.5$ & 0.363 \\
\hline Females / Males, n (\%) & $166(80.5) / 40(19.5)$ & 169 (83.7) /35 (16.3) & $42(71.2) / 17(28.8)$ & 0.139 \\
\hline Obesity frequency $\left(\mathrm{IMC}>30 \mathrm{~kg} / \mathrm{m}^{2}\right), \mathrm{n}(\%)$ & $55(26.8)$ & $63(32)$ & $15(25.4)$ & 0.431 \\
\hline Total cholesterol serum level, mg/dl & $172.5 \pm 25.3$ & $167.9 \pm 45.1$ & $152.2 \pm 39.0$ & $<.001^{\neq, *,+}$ \\
\hline HDL cholesterol serum level, mg/dl & $46.0 \pm 11.6$ & $43.8 \pm 14.5$ & $46.0 \pm 18.7$ & 0.198 \\
\hline LDL cholesterol serum level, mg/dl & $96.7 \pm 29.4$ & $84.0 \pm 39.5$ & $76.9 \pm 32.5$ & $0.014^{*}$ \\
\hline VLDL cholesterol serum level, mg/dl & $28.9 \pm 14.8$ & $41.2 \pm 23.0$ & $37.6 \pm 21.3$ & $<.001^{\ddagger,+}$ \\
\hline Triglyceridesserum level, mg/dl & $142.7 \pm 87.1$ & $208.3 \pm 119.7$ & $172.8 \pm 88.1$ & $<.001^{\neq, *,+}$ \\
\hline Hypocholesterolemia frequency (<150 mg/dl), n (\%) & $28(13.6)$ & $79(38.2)$ & $29(49.2)$ & $<.001$ \\
\hline
\end{tabular}

MDD Major depression disorder

Values are mean \pm standard deviation

* Statistically significant difference between Healthy subjects and MDD associated with suicide attempt

${ }^{+}$Statistically significant difference between MDD and MDD associated with suicide attempt

${ }^{\ddagger}$ Statistically significant difference between Healthy subjects and MDD

significantly lower total cholesterol levels compared with MDD only ( $p$ 0.016).

LDL levels were lower in the MDD associated with suicide attempt group with respect to the control group ( $p$ 0.013). Subjects with depression presented higher VLDL $(p<0.001)$ and triglyceride levels $(p<0.001)$ compared with healthy controls. Similarly, subjects with depression presented higher VLDL ( $\mathrm{p}$ 0.043) and triglyceride levels (p 0.039) compared with MDD with suicide attempt. The frequency of hypocholesterolemia was significantly higher in the MDD and MDD with suicide attempt groups compared with the control group $(p<0.001)$.

A subgroup analysis by gender was performed in order to separately assess the magnitude of the association between lipid serum levels in men and women with MDD and suicide attempt (Table 2). Both, men and women showed significantly lower total cholesterol levels in subjects with MDD associated with suicide attempt compared with the control group $(p<0.05)$. However, only in women, did we observe a significant difference between the MDD-only

Table 2 Analysis by gender of clinical characteristics and laboratory parameters

\begin{tabular}{|c|c|c|c|c|c|c|c|c|}
\hline & \multicolumn{3}{|l|}{ Male } & \multirow[t]{2}{*}{$p$ value } & \multicolumn{3}{|l|}{ Female } & \multirow[t]{2}{*}{$p$ value } \\
\hline & $\begin{array}{l}\text { Healthy } \\
\text { subjects }\end{array}$ & MDD & $\begin{array}{l}\text { MDD associated } \\
\text { w/suicide attempt }\end{array}$ & & $\begin{array}{l}\text { Healthy } \\
\text { subjects }\end{array}$ & MDD & $\begin{array}{l}\text { MDD associated } \\
\text { w/suicide attempt }\end{array}$ & \\
\hline$n$ & 40 & 36 & 17 & & 166 & 171 & 42 & \\
\hline Age, years & $38.1 \pm 6.1$ & $35.8 \pm 10.5$ & $37.3 \pm 11.9$ & 0.592 & $36.5 \pm 6.7$ & $37.5 \pm 10.0$ & $34.3 \pm 9.9$ & 0.133 \\
\hline $\begin{array}{l}\text { Obesity frequency } \\
\left(\mathrm{IMC}>30 \mathrm{~kg} / \mathrm{m}^{2}\right), \mathrm{n}(\%)\end{array}$ & $10(25)$ & $6(17.1)$ & $3(17.6)$ & 0.664 & $45(27.3)$ & $57(34.8)$ & $12(28.6)$ & 0.322 \\
\hline $\begin{array}{l}\text { Total cholesterol serum } \\
\text { level, mg/dl }\end{array}$ & $182.5 \pm 42.5$ & $164.8 \pm 48.6$ & $140.2 \pm 32.1$ & $0.002^{\neq, *}$ & $170.1 \pm 18.4$ & $168.5 \pm 44.4$ & $157.1 \pm 40.8$ & $0.017^{*}$ \\
\hline $\begin{array}{l}\text { HDL cholesterol serum } \\
\text { level, mg/dl }\end{array}$ & $46.4 \pm 14.5$ & $41.7 \pm 15.8$ & $44.1 \pm 12.4$ & 0.566 & $45.8 \pm 10.2$ & $44.2 \pm 14.2$ & $46.8 \pm 20.9$ & 0.301 \\
\hline $\begin{array}{l}\text { LDL cholesterol serum } \\
\text { level, mg/dl }\end{array}$ & $100.8 \pm 35.9$ & $71.2 \pm 37.2$ & $71.7 \pm 24.5$ & $0.011^{\ddagger}$ & $94.8 \pm 26.2$ & $86.7 \pm 39.5$ & $78.9 \pm 35.3$ & 0.165 \\
\hline $\begin{array}{l}\text { VLDL cholesterol serum } \\
\text { level, mg/dl }\end{array}$ & $30.9 \pm 17.0$ & $55.4 \pm 33.4$ & $29.8 \pm 10.1$ & $0.002^{\neq, \dagger}$ & $28.1 \pm 13.9$ & $38.1 \pm 18.9$ & $34.9 \pm 18.7$ & $0.004^{\ddagger}$ \\
\hline Triglycerides serum level, mg/dl & $137.7 \pm 66.9$ & $277.1 \pm 167.2$ & $157.6 \pm 60.2$ & $<.001^{\ddagger, \dagger}$ & $143.9 \pm 91.4$ & $193.7 \pm 101.8$ & $179.0 \pm 97.2$ & $<.001^{\neq, *}$ \\
\hline $\begin{array}{l}\text { Hypocholesterolemia } \\
\text { frequency (<150 mg/dl), n (\%) }\end{array}$ & $8(20)$ & $17(47.2)$ & $9(52.9)$ & 0.015 & $20(12)$ & $62(36.3)$ & $20(47.6)$ & $<.001$ \\
\hline
\end{tabular}

Values are mean \pm standard deviation

* Statistically significant difference between Healthy subjects and MDD associated with suicide attempt

†Statistically significant difference between MDD and MDD associated with suicide attempt

¥Statistically significant difference between Healthy subjects and MDD 
group versus the control group. No such relationship was seen in males. The comparative analysis of the hypocholesterolemia frequency between the study groups showed significant differences in both genders $(p<0.05)$.

A bivariate logistic regression using data matched on age, sex, and BMI showed a statistically significant association between hypocholesterolemia and MDD (OR 4.229 $C I 95 \% 2.555-7.000, p<0.001)$. In the same way, a statistically significant association between hypocholesterolemia and suicide attempt was observed (OR 5.540 CI 95\% 2.825 - 10.866, $p<0.001$ ). Additionally, triglycerides were analyzed and we found the following Odds Ratios and 95\% Confidence Intervals: for hypertriglyceridemia in MDD [3.528 (2.326-5.352); $p<0.001$ ]; for hypertriglyceridemia in MDD with suicide attempt [2.626 (1.411-4.885); $p=0.002$ ]. Upon further analysis, no significant association in the other variables.

\section{Discussion}

Here, we show that lower serum cholesterol levels are linked with MDD and suicide attempt. Age and sex-adjusted analyses showed a clear association between serum cholesterol levels and the risk of depression and suicide attempt.

Previously, some studies have also shown an association between low cholesterol and increased risk of death due to injuries or suicide [2, 9, 26-29], but not in other reports [1,30-33], even elevated cholesterol levels have been associated with suicide mortality in other studies $[15,33]$.

In Mexican subjects, there is only one research paper that has examined the possible link with hypocholesterolemia and suicide attempt in subjects with depression [34]. This study found no difference in lipid profiles between patients who had attempted suicide and those who had not. However, these authors studied only 33 patients with a major depressive episode (moderate to severe) comparing 18 subjects who had attempted suicide versus subjects who had never attempted suicide.

Although there is evidence of a link between low serum cholesterol levels and suicide in patients with depression [35, 36], the mechanism that may link serum lipids with suicidality is still unclear. It has been established that nearly all brain cholesterol is produced in situ through de novo synthesis and that adequate prevention of its uptake from the bloodstream is provided by selectivity of the blood-brain barrier [37-39]. Nonetheless, it is viable that decreased peripheral cholesterol in those individuals with psychiatric disorders occurs concurrently with cholesterol modifications that take place in distinct synaptic lipid rafts in neurons (by a common regulatory mechanism). This could produce the minimized activity of serotonergic communication and, consequently, give rise to instinctive responses and violent suicidal behavior $[2,40]$.
Cholesterol is the paramount constituent of cellular membranes in higher eukaryotes and is essential in membrane function and organization as well as dynamics and sorting. It is commonly found dispersed in a non-random form in specific areas (domains) in both biological and model membranes [41-43]. These areas, often denominated as 'lipid rafts' [43, 44], are thought to be fundamental in the preservation of the structure and function of the membrane. However, describing the spatiotemporal resolution of these domains has turned out to be a difficult task $[43,45]$. It has been suggested that these formations be membrane domains in which signaling from a neurotransmitter may arise via a group of receptors, such as serotonin $_{1 \mathrm{~A}}\left(5-\mathrm{HT}_{1 \mathrm{~A}}\right)$ receptor [46].

Previous studies demonstrated the imperative necessity of membrane cholesterol in the function and organization of the $5-\mathrm{HT}_{1 \mathrm{~A}}$ receptor $[45,47-52]$. Results from additional studies showed that the fluidity of lipids considerably regulates the binding of serotonin $(5-\mathrm{HT})$ in murine brain membranes. It is therefore expected that decreased levels of cholesterol would increase the fluidity of the cellular membrane. While, at the same time, minimal exposure of the 5HT receptors would be found in the synaptic cleft $[2,53]$.

Reportedly, disturbance of rafts by cholesterol deficiency notably lowers agonist binding and coupling of $\mathrm{G}$ protein to 5-hydroxytryptamine 1A (5-HT1A) serotonin receptors in bovine hippocampal membranes [46, 47]. Serotonin ${ }_{1 \mathrm{~A}}$ receptors typify one of the most formidable, evolutionarily primitive, yet largely conserved families of seven transmembrane $G$ protein-coupled receptors (GPCRs) that span the membrane $[45,54]$. Also, serotonergic signaling constitutes an important part in the formation and regulation of a multitude of functions such as behavioral, cognitive, and developmental [45]. Moreover, studies have demonstrated that there is an association between decreased 5-HT activity and suicide $[2,55]$.

It is noteworthy to mention that recent studies described crystal structures of GPCRs, including serotonin ${ }_{1 \mathrm{~A}}$ receptor, that demonstrated structural proof of cholesterol binding sites $[45,56,57]$.Currently, two conceivable pathways have been proposed by which membrane cholesterol could affect the structure and function of GPCRs: (i) by way of a direct/specific interaction with GPCRs, or (ii) via an indirect pathway by modifying the physical properties of the membrane in which the receptor is inserted, or as a result of an integration of both $[45,58]$.

About cholesterol levels and their relation to gender, our study showed that the decrease in total cholesterol levels occurred in both men and women. Other authors have reported a relationship between reduced cholesterol and suicidal tendencies only in males [13,59-62]. However, it is worth noting that additional studies on the association between gender and serum cholesterol have been unconvincing. 
A lack of consistency between different published reports coupled with the fact that, to date, it has not been possible to identify a cholesterol threshold level capable of precipitating a psychiatric disorder, suggests the presence of a non-linear relationship.

The existence of reports in which depression has been associated with increased cholesterol levels would support this hypothesis. A possible explanation for this, proposed the involvement of monoamine oxidase (MAO). The aforementioned model studies associated hypercholesterolemia with depression in hypercholesterolemic mice via monoaminergic metabolism. Specifically, they reported increased monoamine oxidase (MAO) A and B activity in the hippocampus of mice $[63,64]$. Thus providing one possible reason why elevated levels of cholesterol are able to produce depression much like decreased levels are able to, but via independent mechanisms.

Besides total cholesterol, other studies that investigated the link between triglycerides, HDL cholesterol and LDL cholesterol, observed contrasting results between different populations. Our results showed higher levels of triglycerides in subjects with MDD and MDD associated with suicide attempt. These findings do not coincide with data previously reported in 2015 that observed decreased levels of triglycerides in subjects with suicidal attempts [65]. However, other authors report conflicting findings, even suggesting a positive association between triglyceride levels and the risk of suicidal behavior [15]. Considering LDL cholesterol levels, our results coincide with the conclusions of a meta-analysis published in 2016, which included a total of 36 different studies and found overall association between lower LDL levels and depression [66]. With respect to VLDL levels, which were significantly higher in MDD versus healthy controls, it is worth noting that few studies report VLDL levels. Taking this into consideration, our result is different from the result reported in a previous study [67] that showed significantly lower levels while our results demonstrate higher levels. With respect to HDL cholesterol levels, our results did not demonstrate significant differences when comparing subjects with MDD, subjects with MDD associated with suicide attempt and the control group. This fact contrasts with previous studies in which significant differences in HDL cholesterol between subjects with attempted suicide and healthy controls were shown $[59,68]$.

Lastly, we found a significant association between elevated triglyceride levels versus MDD and MDD with suicide attempt. Our finding coincides with a previous study which found a correlation between depressive symptoms and triglyceride levels [69] and suggestions by others which postulate that high triglyceride levels are associated with Type A personality traits, such as hostility, anger and domineering attitudes [70].
Several limitations of this study deserve to be mentioned. First, because our study is based on a case-control design, temporality could be not inferred with certainty. Whether hypocholesterolemia is a risk factor for developing depression and suicide attempt or merely an associated epiphenomenon can not be assured with certainty; second, we did not measure 24. S-hydroxycholesterol levels, which is a peripheral biomarker of brain cholesterol metabolism. However, it is expected that reduction of total cholesterol would reduce 24 S-hydroxycholesterol [71]. Besides, we did not evaluate dietary intake; however, because subjects in the groups of the study were enrolled from the same socio-cultural and economic background, it is expected that customary diets were similarly distributed. Finally, an additional limitation of our study is that we did not analyze the cardiovascular risk associated with serum cholesterol concentrations. In the future, it will be important to profoundly analyze the contradictory results reported with regard to cholesterol's role in depression. $[63,64]$. This would help to verify if cholesterol is, in fact, a viable biomarker for neuropsychiatric disorders. It is evident that these results may be extrapolated only to a population that is similar to our own with similar exclusion criteria. Strengths of our study include the inclusion of incident cases of suicide attempt, which is a recognized tool to minimize analysis bias in the cross-sectional studies; also, the exclusion of individuals with lipid-lowering drugs allows us to control the potential source of bias.

\section{Conclusions}

In conclusion, our results show that hypocholesterolemia is independently associated with depression and suicide attempt in adults of the Mexican population .This finding, if consistent in more studies in our population, could influence public health policies focused in the prevention of mental health disorders. Measuring cholesterol levels could be a minimally invasive, inexpensive and simple way to predict suicide risk in our population. The use of cholesterol levels as a biomarker would permit clinicians to efficiently obtain a laboratory result that, once combined with clinical evaluations and symptoms, could permit a more timely diagnosis. Additionally, it would be necessary to calculate the sensibility and specificity of this test in our population.

\section{Abbreviations \\ CHOL: Cholesterol; HDL: High-density lipoprotein; LDL: Low-density lipoprotein; MDD: Major depressive disorder; VLDL: Very low-density lipoprotein}

\section{Acknowledgements}

We would like to thank the Department of Education from the Mental Health Hospital "Dr. Miguel Valle Bueno" (Secretary of Health) and Department of Psychiatry from General Hospital 450 (Secretary of Health) and General Hospital "Dr. Santiago Ramón y Cajal" (ISSSTE).

Funding

Materials used in the experimental stages were obtained through FOSISS CONACYT-2015 (Grant 261453). The funding body did not participate in the design of the study and collection, analysis, and interpretation of data and in writing the manuscript. 


\section{Availability of data and materials}

The datasets used and/or analyzed during the current study are available from the corresponding author on reasonable request.

\section{Authors' contributions}

$\mathrm{EMH}$ and FCJ conceived and designed the experiments; MCC, EMM and MSM performed the experiments; OLL and JSP analyzed the data; OAC and MBS contributed analysis tools; FVA, JMH and EMM wrote the paper. All authors read and approved the final manuscript

\section{Ethics approval and consent to participate}

The protocol was approved by the Ethics Committee for Research of the General Hospital 450, Secretary of Health of Durango (No. 12/0306-2015). Informed consent was obtained from participants was in written form.

\section{Consent for publication}

Not applicable

\section{Competing interests}

The authors declare that they have no competing interests

\section{Publisher's Note}

Springer Nature remains neutral with regard to jurisdictional claims in published maps and institutional affiliations.

\begin{abstract}
Author details
'Instituto de Investigación Científica, Universidad Juárez del Estado de Durango, Universidad S/N esquina Volantín Zona Centro CP 34000, Zip Code 34000 Av., Durango, Mexico. ${ }^{2}$ Hospital General 450, Servicios de Salud de Salud, Zip Code 34206, Durango, México. ${ }^{3}$ Departamento de Biotecnología, Universidad Autónoma Metropolitana, Ciudad de México, MéxicoZip Code 09340. ${ }^{4}$ Facultad de Ciencias Químicas, Universidad Juárez del Estado de Durango, Zip Code 34000, Durango, México. ${ }^{5}$ Unidad de Trastornos del Movimiento y Sueño (TMS), Hospital General Dr. Manuel Gea González, Zip Code 14080, Ciudad de México, México. 'Subdirección de Investigación en Salud, Servicios de Salud de Durango, Zip Code 34000., Durango, México.
\end{abstract}

Received: 5 July 2017 Accepted: 8 January 2018

Published online: 15 January 2018

\section{References}

1. Baek JH, Kang ES, Fava M, Mischoulon D, Nierenberg AA, Yu BH, et al. Serum lipids, recent suicide attempt and recent suicide status in patients with major depressive disorder. Prog Neuropsychopharmacol Biol Psychiatry. 2014;51:113-8. doi:10.1016/j.pnpbp.2014.01.018.

2. Wu S, Ding Y, Wu F, Xie G, Hou J, Mao P. Serum lipid levels and suicidality: a meta-analysis of 65 epidemiological studies. J Psychiatry Neurosci. 2016;41:56-69.

3. Kay M. Suicide is leading cause of death in young Indian women, finds the international study. BMJ. 2013;346:f1900. doi:10.1136/bmj.f1900.

4. O'Connor E, Gaynes BN, Burda BU, Soh C, Whitlock EP. Screening for and treatment of suicide risk relevant to primary care: a systematic review for theU.S. Preventive Services Task Force. Ann Intern Med. 2013;158:741-54. doi:10.7326/0003-4819-158-10-201305210-00642.

5. Día Mundial para la Prevención del Suicidio. http://bibliodigitalibd.senado. gob.mx/handle/123456789/3181. Accessed 31 October 2017.

6. Mann JJ. A current perspective of suicide and attempted suicide. Ann Intern Med. 2002;136:302-11.

7. Lee BH, Kim YK. Potential peripheral biological predictors of suicidal behavior in major depressive disorder. Prog Neuropsychopharmacol Biol Psychiatry. 2011;35:842-7. doi:10.1016/j.pnpbp.2010.08.001.

8. Carlson GA, Rich CL, Grayson P, Fowler RC. Secular trends in psychiatric diagnoses of suicide victims. J Affect Disord. 1991;21:127-32.

9. Messaoud A, Mensi R, Mrad A, Mhalla A, Azizi I, Amemou B, et al. Is low total cholesterol levels associated with suicide attempt in depressive patients? Ann Gen. Psychiatry. 2017;16:20. doi:10.1186/s12991-017-0144-4.

10. Asellus P, Nordstrom P, Jokinen J. Cholesterol and CSF 5-HIAA in attempted suicide. J Affect Disord. 2010;125:388-92. doi:10.1016/j.jad.2010.02.111.

11. Lee HJ, Kim YK. Serum lipid levels and suicide attempts. Acta Psychiatr Scand. 2003;108:215-21.

12. Huang TL. Serum lipid profiles in major depression with clinical subtypes, suicide attempts and episodes. J Affect Disord. 2005;86:75-9.
13. Diaz-Sastre C, Baca-Garcia E, Perez-Rodriguez MM, Garcia-Resa E, Ceverino A, Saiz-Ruiz J, et al. Low plasma cholesterol levels in suicidal males: a genderand body mass index-matched case-control study of suicide attempters and nonattempters. Prog Neuropsychopharmacol Biol Psychiatry. 2007:31:901-5.

14. Kim YK, Lee HJ, Kim JY, Yoon DK, Choi SH, Lee MS. Low serum cholesterol is correlated to suicidality in a Korean sample. Acta Psychiatr Scand. 2002;105:141-8.

15. Brunner J, Bronisch T, Pfister H, Jacobi F, Höfler M, Wittchen HU. High cholesterol, triglycerides, and body-mass index in suicide attempters. Arch Suicide Res. 2006;10:1-9.

16. Fiedorowicz JG, Coryell WH. Cholesterol and suicide attempts: a prospective study of depressed inpatients. Psychiatry Res. 2007;152:11-20.

17. De Leon J, Mallory P, Maw L, Susce MT, Perez-Rodriguez MM, Baca-Garcia E. Lack of replication of the association of low serum cholesterol and attempted suicide in another country raises more questions. Ann Clin Psychiatry. 2011;23:163-70.

18. Deisenhammer EA, Kramer-Reinstadler K, Liensberger D, Kemmler G, Hinterhuber $\mathrm{H}$, Fleischhacker WW. No evidence for an association between serum cholesterol and the course of depression and suicidality. Psychiatry Res. 2004:121:253-61.

19. Roy A, Roy M. No relationship between serum cholesterol and suicidal ideation and depression in African-American diabetics. Arch Suicide Res. 2006:10:11-4.

20. Violence Prevention. https://www.cdc.gov/violenceprevention/suicide/ definitions.html. Accessed 14 Jan 2018.

21. Shamai L, Lurix E, Shen M, Novaro GM, Szomstein S, Rosenthal R, et al. Association of body mass index and lipid profiles: evaluation of a broad spectrum of body mass index patients including the morbidly obese. Obes Surg. 2011;21:42-7. doi:10.1007/s11695-010-0170-7.

22. Bu DX, Griffin G, Lichtman AH. Mechanisms for the anti-inflammatory effects of statins. Curr Opin Lipidol. 2011;22:165-70. doi:10.1097/MOL.0b013e3283453e41.

23. Redlich C, Berk M, Williams LJ, Sundquist J, Sundquist K, Li X. Statin use and risk of depression: a Swedish national cohort study. BMC psychiatry. 2014;14: 348. doi:10.1186/s12888-014-0348-y.

24. Dalal JJ, Padmanabhan TNC, Jain P, Patil S, Vasnawala H, Gulati A. LIPITENSION: Interplay between dyslipidemia and hypertension. Indian 」 Endocrinol Metab. 2012;16:240. doi:10.4103/2230-8210.93742.

25. Schofield JD, Liu Y, Rao-Balakrishna P, Malik RA, Soran H. Diabetes dyslipidemia. Diabetes Ther. 2016;7:203-19. doi:10.1007/s13300-016-0167-X.

26. Muldoon MF, Manuck SB, Matthews KA. Lowering cholesterol concentrations and mortality: a quantitative review of primary prevention trials. BMJ. 1990;301:309-14.

27. Lindberg G, Råstam L, Gullberg B, Eklund GA. Low serum cholesterol concentration and short term mortality from injuries in men and women. BMJ. 1992;305:277-9.

28. Neaton JD, Blackburn $H$, Jacobs D, Kuller L, Lee DJ, Sherwin R, et al. Serum cholesterol level and mortality findings for men screened in the Multiple Risk Factor Intervention Trial. Arch Intern Med. 1992;152:1490-500.

29. Zureik $M$, Courbon D, Ducimetière P. Serum cholesterol concentration and death from suicide in men: Paris prospective study I. BMJ. 1996;313:649-51.

30. Jacobs D, Blackburn H, Higgins M, Reed D, Iso H, McMillan G, et al. Report of the Conference on Low Blood Cholesterol: Mortality Associations. Circulation. 1992:86:1046-60.

31. Vartiainen E, Puska P, Pekkanen J, Tuomilehto J, Lönnqvist J, Ehnholm C. Serum cholesterol concentration and mortality from accidents, suicide, and other violent causes. BMJ. 1994;309:445-7.

32. Apter A, Laufer N, Bar-Sever M, Har-Even D, Ofek H, Weizman A. Serum cholesterol, suicidal tendencies, impulsivity, aggression, and depression in adolescent psychiatric inpatients. Biol Psychiatry. 1999;46:532-41.

33. Tanskanen A, Vartiainen E, Tuomilehto J, Viinamäki H, Lehtonen J, Puska P. High serum cholesterol and risk of suicide. Am J Psychiatry. 2000;157:648-50.

34. Almeida-Montes LG, Valles-Sanchez V, Moreno-Aguilar J, Chavez-Balderas RA, García-Marín JA, Sotres JC, et al. Relation of serum cholesterol, lipid, serotonin and tryptophan levels to severity of depression and to suicide attempts. J Psychiatry Neurosci. 2000;25:371-7.

35. De Berardis D, Marini S, Piersanti M, Cavuto M, Perna G, Valchera A, et al. The Relationships between Cholesterol and Suicide: An Update. ISRN Psychiatry. 2012:387901. doi:10.5402/2012/387901.

36. Park YM, Lee BH, Lee SH. The association between serum lipid levels, suicide ideation, and central serotonergic activity in patients with major depressive disorder. J Affect Disord. 2014;159:62-5. doi:10.1016/j.jad.2014.01.016.

37. Dietschy JM, Turley SD. Cholesterol metabolism in the brain. Curr Opin Lipidol. 2001;12:105-12. 
38. Suzuki R, Lee K, Jing E, Biddinger SB, McDonald JG, Montine TJ, et al. Diabetes and insulin in regulation of brain cholesterol metabolism. Cell Metab. 2010;12:567-79. doi:10.1016/j.cmet.2010.11.006.

39. Reiss AB, Siller KA, Rahman MM, Chan ES, Ghiso J, de Leon MJ. Cholesterol in neurologic disorders of the elderly: stroke and Alzheimer's disease. Neurobiol Aging. 2004;25:977-89.

40. Cantarelli MG, Tramontina AC, Leite MC, Gonçalves CA. Potential neurochemical links between cholesterol and suicidal behavior. Psychiatry Res. 2014;220:745-51. doi:10.1016/j.psychres.2014.10.017.

41. Mouritsen OG, Zuckermann MJ. What's so special about cholesterol? Lipids. 2004;39:1101-13.

42. Mukherjee S, Maxfield FR. Membrane domains. Annu Rev Cell Dev Biol. 2004;20:839-66

43. Jacobson K, Mouritsen OG, Anderson RGW. Lipid rafts: at a crossroad between cell biology and physics. Nat Cell Biol. 2007;9:7-14.

44. Lingwood D, Simons K. Lipid rafts as a membrane-organizing principle. Science. 2010;327:46-50. doi:10.1126/science.1174621.

45. Jafurulla M, Tiwari S, Chattopadhyay A. Identification of cholesterol recognition amino acid consensus (CRAC) motif in G-protein coupled receptors. Biochem Biophys Res Commun. 2011;404:569-73. doi:10.1016/j.bbrc.2010.12.031.

46. Allen JA, Halverson-Tamboli RA, Rasenick MM. Lipid raft microdomains and neurotransmitter signalling. Nat Rev Neurosci. 2007;8:128-40.

47. Pucadyil TJ, Chattopadhyay A. Cholesterol modulates the ligand binding and G-protein coupling to serotonin1A receptors from bovine hippocampus. Biochim Biophys Acta. 2004;1663:188-200.

48. Pucadyil TJ, Chattopadhyay A. Role of cholesterol in the function and organization of G-protein coupled receptors. Prog Lipid Res. 2006;45:295-333.

49. Pucadyil TJ, Chattopadhyay A. Cholesterol depletion induces dynamic confinement of the G-protein coupled serotonin1A receptor in the plasma membrane of living cells. Biochim Biophys Acta. 2007;1768:655-68.

50. Paila YD, Murty MR, Vairamani M, Chattopadhyay A. Signaling by the human serotonin1A receptor is impaired in cellular model of Smith-Lemli-Optiz Syndrome. Biochim Biophys Acta. 2008;1778:1508-16. doi:10.1016/j.bbamem.2008.03.002.

51. Paila YD, Chattopadhyay A. Membrane cholesterol in the function and organization of G-protein coupled receptors. Subcell Biochem. 2010;51:43966. doi:10.1007/978-90-481-8622-8_16.

52. Shrivastava S, Pucadyil TJ, Paila YD, Ganguly S, Chattopadhyay A. Chronic cholesterol depletion using statin impairs the function and dynamics of human serotonin1A receptors. Biochemistry. 2010;49:5426-35. doi:10.1021/bi100276b.

53. Heron DS, Shinitzky M, Hershkowitz M, Samuel D. Lipid fluidity markedly modulates the binding of serotonin to mouse brain membranes. Proc Natl Acad Sci U S A. 1980;77:7463-7.

54. Pucadyil TJ, Kalipatnapu S, Chattopadhyay A. The serotonin1A receptor: a representative member of the serotonin receptor family. Cell Mol Neurobiol. 2005:25:553-580.

55. Asberg M, Träskman L, Thorén P. 5-HIAA in the cerebrospinal fluid. A biochemical suicide predictor? Arch Gen Psychiatry. 1976;33:1193-7.

56. Cherezov V, Rosenbaum DM, Hanson MA, Rasmussen SG, Thian FS, Kobilka TS, et al. High-resolution crystal structure of an engineered human $\beta 2$ adrenergic G protein-coupled receptor. Science. 2007;318:1258-65.

57. Hanson MA, Cherezov V, Griffith MT, Roth CB, Jaakola VP, Chien EY, et al. A specific cholesterol binding site is established by the $2.8 \AA$ structure of the human $\beta 2$ adrenergic receptor. Structure. 2008;16:897-905. doi:10.1016/.str.2008.05.001.

58. Paila YD, Chattopadhyay A. The function of G-protein coupled receptors and membrane cholesterol: specific or general interaction? Glycoconj J. 2009;26:711-20. doi:10.1007/s10719-008-9218-5.

59. Maes M, Smith R, Christophe A, Vandoolaeghe E, Van Gastel A, Neels H, et al. Lower serum high-density lipoprotein cholesterol (HDL-C) in major depression and in depressed men with serious suicide attempts: relationship with immune inflammatory markers. Acta Psychiatr Scand. 1997;95:212-21.

60. Bocchetta A, Chillotti C, Carboni G, Oi A, Ponti M, Del Zompo M. Association of personal and familial suicide risk with low serum cholesterol concentration in male lithium patients. Acta Psychiatr Scand. 2001;104:37-41.

61. Golier JA, Marzuk PM, Leon AC, Weiner C, Tardiff K. Low serum cholesterol level and attempted suicide. Am J Psychiatry. 1995;152:419-23.

62. Soeda S, Terao T, Iwata N, Abe H, Uchida K, Nakamura J. Mental effect of cholesterol in males: protective effect? J Affect Disord. 2006;91:139-44. doi:10.1016/j.jad.2005.10.012.

63. Svensson T, Inoue M, Sawada N, Charvat H, Mimura M, Tsugane S. High serum total cholesterol is associated with suicide mortality in Japanese women. Acta Psychiatr Scand. 2017;136:259-68. doi:10.1111/acps.12758.
64. Engel DF, de Oliveira J, Lopes JB, Santos DB, Moreira ELG, Farina M, et al. Is there an association between hypercholesterolemia and depression? Behavioral evidence from the LDLr-/- mouse experimental model. Behav Brain Res. 2016:311:31-8. doi:10.1016/j.bbr.2016.05.029.

65. da Graça Cantarelli M, Nardin P, Buffon A, Eidt MC, Godoy LA, Fernandes BS, et al. Serum triglycerides, but not cholesterol or leptin, are decreased in suicide attempters with mood disorders. J Affect Disord. 2015;172:403-9. doi:10.1016/j.jad.2014.10.033.

66. Persons JE, Fiedorowicz JG. Depression and serum low-density lipoprotein: A systematic review and meta-analysis. J Affect Disord. 2016;206:55-67. doi:10.1016/j.jad.2016.07.033.

67. Kale AB, Kale SB, Chalak SS, Tankhiwale SR, Bang G, Agrawal M, Kaple M. Lipid parameters-significance in patients with endogenous depression. J Clin Diagn Res. 2014;8:17-9. doi:10.7860/JCDR/2014/4059.3911.

68. Zhang J, McKeown RE, Hussey JR, Thompson SJ, Woods JR, Ainsworth BE. Low HDL cholesterol is associated with suicide attempt among young healthy women: the Third National Health and Nutrition Examination Survey. J Affect Disord. 2005;89:25-33.

69. Huang TL, Chen JF. Lipid and lipoprotein levels in depressive disorders with melancholic feature or atypical feature and dysthymia. Psychiatry Clin Neurosci. 2004;58:295-9.

70. Tzavellas E, Karaiskos D, Paparrigopoulos T. Triglycerides, Depression, and Risk of Ischemic Stroke. Jama. 2009;3011338-1339. doi: 10.1001/jama.2009.410.

71. Bretillon L, Lütjohann D, Ståhle L, Widhe T, Bindl L, Eggertsen G, et al. Plasma levels of 24S-hydroxycholesterol reflect the balance between cerebral production and hepatic metabolism and are inversely related to body surface. J Lipid Res. 41:840-5.

\section{Submit your next manuscript to BioMed Central and we will help you at every step:}

- We accept pre-submission inquiries

- Our selector tool helps you to find the most relevant journal

- We provide round the clock customer support

- Convenient online submission

- Thorough peer review

- Inclusion in PubMed and all major indexing services

- Maximum visibility for your research

Submit your manuscript at www.biomedcentral.com/submit
Biomed Central 